\title{
ВІДБИТТЯ ПОДІЛЬСЬКИХ ГОВІРКОВИХ РИС У ПРАЦЯХ ПОЛЬСЬКИХ ДОСЛІДНИКІВ К. ХІХ СТ.
}

\author{
БОРИС КОВАЛЕНКО \\ Кам’янець-Подільський національний університет імені Івана Огієнка, \\ Кам'янець-Подільський - Україна \\ kovalenko.bor@gmail.com; ORCID: 0000-0002-3764-856X
}

НАТАЛІЯ КОВАЛЕНКО

Кам'янець-Подільський національний університет імені Івана Огієнка, Кам'янець-Подільський - Україна kovalenko.bor@gmail.com; ORCID: 0000-0002-7810-1982

\section{ODZWIERCIEDLENIE CECH GWARY PODOLSKIEJ W PRACACH POLSKICH BADACZY KOŃCA XIX WIEKU}

\author{
BORYS KOWAŁENKO \\ Narodowy Uniwersytet imienia Iwana Ohijenki w Kamieńcu Podolskim, \\ Kamieniec Podolski - Ukraina \\ NATALIA KOWAŁENKO \\ Narodowy Uniwersytet imienia Iwana Ohijenki w Kamieńcu Podolskim, \\ Kamieniec Podolski - Ukraina
}

STRESZCZENIE. Do dziś aktualna pozostaje kwestia zbadania właściwości rozwoju poziomów strukturalnych dialektów, w szczególności utrwalonych w tych cennych źródłachjęzyka ludowego, które nasi poprzednicy pozostawili jako spuściznę w postaci różnych gatunków. Celem artykułu jest określenie stopnia odzwierciedlenia zjawisk gwarowych w zbiorach folklorystycznych i etnograficznych oraz pracach leksykograficznych polskich badaczy Podola. Zastosowano metodę opisowo-porównawczą. Ocenie podlegały osiągnięcia w badaniu etnografii i folkloru podolskiego polskich autorów XIX w., którzy opisali w swoich pracach poszczególne aspekty kultury materialnej i duchowej Ukraińców Podola. Ogromną wartość dla badaczy, zarówno etnografów, folklorystów, jak i lingwistów, zwłaszcza w dziedzinie dialektologii, stanowi bogata folklorystyczna oraz etnograficzna spuścizna A. Kocipińskiego i Z Dołęgi-Chodakowskiego. Ich zapiskizawierają warianty, 
rejestrują wpływ mowy lokalnej, tradycji itp. Równie cenny jest słowniczek regionalizmów podolskich A. Kremera, który uważany jest za pierwsze dzieło leksykograficzne o podolskiej gwarze języka ukraińskiego. W artykule udowodniono, że tylko autentyczne teksty mogą służyć jako cenne i wiarygodne źródło badania dynamiki dialektów Podola.

Słowa kluczowe: badania dialektologiczne, zapiski folklorystyczne i etnograficzne, gwary Podola, cechy lingwalne

\title{
REFLECTION OF PODILLYA DIALECT FEATURES IN WORKS OF POLISH RESEARCHERS OF THE LATE 19TH CENTURY
}

\author{
BORYS KOVALENKO \\ Kamyanets-Podilskiy Ivan Ohiyenko State University, \\ Kamyanets-Podilskiy - Ukraine \\ NATALIIA KOVALENKO \\ Kamyanets-Podilskiy Ivan Ohiyenko State University, \\ Kamyanets-Podilskiy — Ukraine
}

\begin{abstract}
The article sets out to find out peculiarities of the development of various structural levels of dialects not only in the present but also those valuable sources of folk language, which were recorded by our ancestors in a multi-genre heritage. The purpose of the study is to reveal the extent to which dialect phenomena were reflected in folklore ethnographic collections and lexicographic works of Polish researchers of Podillya. The main method is a descriptive and comparative one. The analysis sheds the light on achievements of Polish authors of the 19th century in studying the ethnography and folklore of Podillya. It is demonstrated that their works described certain aspects of the material and spiritual culture of Ukrainians of Podillya and have been greatly appreciated by Ukrainian scholars. The great folklore and ethnographic heritage of A. Kotsipinskyi and Z. Dolenha-Khodakovskyi is valuable to ethnographers, folklorists and linguists and especially dialectologists. Of particular importance is the dictionary of Podillya regionalisms by A. Kremer, which is considered to be the first lexicographic work on the Podillya dialect of Ukrainian. It is proved in the article that only authentic texts can serve as a valuable and reliable source for studying the dynamics of dialectal language in Podillya region.
\end{abstract}

Key words: dialectological research, folklore and ethnographic records, Podillya dialects, lingual features

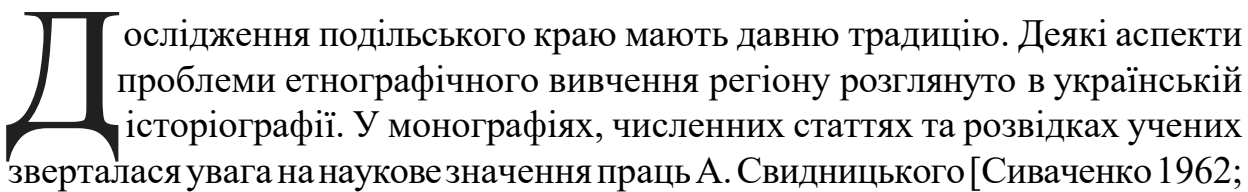


Сиваченко 1974], А. Димінського [Новицький 1980] та Ю. Сіцінського [Паравійчук 1968] для розробки конкретних питань традиційно-побутової культури населення краю. У працях 3. Болтарович [Болтарович 1976], Р. Кирчіва [Кирчів 1971] та В. Юзвенко [Юзвенко 1961] оцінено здобутки у вивченні етнографії та фольклору Поділля польських авторів XIX ст., які описали у своїх наукових розвідках окремі аспекти матеріальної й духовної культури українців Поділля, - Ф.Гіжицького, Ю.Сенковського, В. Марчинського, Л.Голембійовського, О. Пшездецького, Ю. Крашевського. Зокрема, перший у польській етнографічній літературі опис подільського весілля 3 текстами весільних пісень здійснив М. Гославський, а в другому томі книги Стародавня Польща є історичні та етнографічні відомості про Поділля (автори М. Балінський і Т. Ліпінський). Однак основні етапи й напрями дослідження цього регіону до останнього часу не мали широкого та всебічного висвітлення внауковій літературі.

Мета цієї статті — з'ясувати, якою мірою відбилися говіркові явища в фольклорно-етнографічних збірках та лексикографічних працях польських дослідників Поділля.

Цінним джерелом для сучасного дослідника-мовознавця є збірка А. Коціпінського Пісні, думки і шумки руського народу на Поділлі, Україні і в Малоросії [Коціпінський 1862].

Пісенна творчість українців дуже багата й різноманітна, а жанрово українські народні пісні поділяються на історичні, козацькі, календарно-обрядові, ліричні (родинно-побутові, суспільно-побутові та ін.).

Поетичний стиль народної пісні в усіх народів формується на основі використання виразних діалектизмів, прагненні наблизитися до високого стилю й літературної мови. Наддіалектний характер української народнопісенної мови виявляється в тому, що виразні діалектні особливості нейтралізуються або спостерігається міграція слів з одного територіального різновиду мови в інший. Крім того, народнопісенна мова, як жоден інший різновид мови, тривалий час зберігає елементи давньої літературної практики [Срмоленко 1987: 13]. Однією з ознак наддіалектності народної поезії є також “застиглість” епічних формул, архаїчність деяких зворотів. Причиною стирання діалектних особливостей народнопісенної мови був факт “переживання” народної пісні митцем, художником слова, який бачив народний твір на ширшому тлі літературної мови й часто продовжував його творення в нових варіантах [див.: Єрмоленко 1987: 15]. Більшість представників української школи лінгвофольклористики зорієнтована саме на цю тезу, однак у працях Г. Аркушина [Аркушин 2010], І.Гороф'янюк [Гороф'янюк 2013], Ю. Грицевича [Грицевич 2018], П. Гриценка [Гриценко 2014], Ю. Громика [Громик 2015], Н. Данилюк [Данилюк 2001], Б. Коваленка [Коваленко 2009], I. Матвіяса [Матвіяс 2005], Л. Фроляк [Фроляк 2016] та ін. натрапляємо на інші, не менш цінні узагальнення про зв'язок мови фольклору з діалектним середовищем. 
У пісенному мовленні, як свідчать тексти пісень пропонованої збірки, певною мірою відбиваються й фонетичні, і морфологічні, і лексичні, і синтаксичні говіркові риси, зокрема й подільські.

Незважаючи на фольклорну традицію нівелювання локальних фонетичних особливостей, досить помітним явищем $є$ випадання звука або групи звуків у середині слова у формах дієслова хотіти (синкопа), напр.: Ой! Пішовъ я до дівчини люльку закурити, Здерли зъ мене сердачину, тай ще хтіли бити; Дала-жь мене моя мати за кого я хтіла; Зашуміла нагаёчка коломого тіла. Типовою для подільського говору є твердість приголосного [р]. Ця особливість певною мірою відбита в текстах пісень, напр.: Кличетъ мати вечерати, - вечеряйте сами; Нема мого миленького, не буду я зъ вами; Ой! Місяию перекрою, зайди за комору, А зъ кімъ мені любо, мило, най си поговору.

Серед інших фонетичних особливостей подільських говірок, що відображені в текстах жартівливих пісень, виділяємо такі:

1) приголосні в іменниках середнього роду II відміни в позиції після голосних перед давнім закінченням -ьје не подовжуються. Це явище відбивається не тільки в усному мовленні, але й у писемному. Свідченням цього $є$, зокрема, й аналізовані пісні: Або въ воді утоплюся, Або въ камінь розібьюся; Нехай про те люде знають, Що зъ коханя умірають; Ой! Якъ тяжко бідной лозі, Коли вітерь віє; А ще тяжче безъ коханя, Коли серче мліє;

2) здавна вже (з XIV ст.) у східнослов'янських пам'ятках з різних територій починають фіксуватися також форми 3 твердим закінченням, що на письмі передавалося через -mъ чи - $m$. Щоправда, форми на -mъ траплялися зрідка вже в найдавніших пам'ятках XI-XII ст. у багатьох південно-західних говірках, зокрема й у подільських, і дотепер широко вживані форми 3-ї особи одн. теперішнього часу з твердим [т]. Спостерігаємо такі форми й у текстах пісень: Качаю ся, валяю ся, кусають мя блохи; Пусти мене, моя мати, до корчмонькі трохи.

Виокремимо морфологічні особливості подільських говірок, що відбиті в текстах пісень:

1) приголосні [д], [т], [3], [c], [ст], як відомо, уже в найдавніші часи переходили у відповідні шиплячі: [д] $\rightarrow$ [дж]; [т] $\rightarrow$ [ч]; [3] $\rightarrow[ж] ;[$ [c] $\rightarrow[ш] ;$ [ст] $\rightarrow$ [шч] (літеру щ). Ці шиплячі рефлекси зберігаються в сучасній українській мові, зокрема в літературній і в багатьох говорах: ходжу, прошу, ненавиджу тощо. У текстах деяких пісень дієслівні форми 1-ї особи одн. теперішнього часу дієслів II дієвідміни мають форми хожу, сижу, де чергування відбувається, але фонема $[\partial ж]$ заступається фонемою [ж], що характерно для полтавських, південнокиївських і середньочеркаських говірок [Бевзенко 1980: 71-72], напр.: Хожу - нужу, ручки ломлю, вздихаю до неба, зъ тяжкимъ жалёмъ промовляю: долі мені треба; Ходила я въ черевичках зъ жовтими пражками, Теперь хожу по морозі білими ніжками; 
2) у текстах деяких пісень трапляються форми Ор. в. одн. іменників II відміни м'якої та мішаної груп на -ом: Я дівкою піду де схочу, Я ся нічимъ не заклопочу: Ані хлібомъ, ні одежою, Ані мужомъ, ні дитиною; І так же ставокъ, I близенько млинокь, По надь крайомъ горбокь, І вишневий садок;

3) наявність флексії - $u$ замість - $i$ у формі Р. в. одн. іменників III відміни, напр.: Перестань милий, долі нарикати, Памятай свого слова дотримати: Я тобі мъ дала разъ слово вірное, Жиймо до смерти въ вірности обое; Ой! Ко-бъ не ти, дівчинонько, і не твойі очи, Не стоявъ би мій коничокъ до темної ночи. За аналогією ця сама флексія вживається у Н. в. мн. слова око: $А$ не кури, вуйку, люльку въ мойейі хатині, Не викури очи чорні молодий дівчині; Загиньmе, пропадьте, Старіі косьті! Не сушіте, не крушіте Моеймолодости;

4) подільське діалектне мовлення, як і інші південно-західні говори, поряд зформою Зн. в. мене, тебе особових займенників , ти, що збігається з формою Р.в., відбиває давню формумня / мя, тя: Якъ мя будешь покідати, перестань хлібъ йісти, Аби тобі трудно, нудно, коло иниой сісти; Ходитъ воликъ по надъ Дунай, сумненько бориче, Вийди, вийди дівчинонько, бо тя хлопець кличе;

5) у текстах пісень знаходимо й злиті форми минулого часу складеного типу, що $є$ поєднанням основного складника колишнього перфекта (дієприкметника) з допоміжним дієсловом у скороченому, здеформованому вигляді: Просивемь йі, щзобь мене кохала, Щоби іншому серия не давала, А вона не хоче, бо я не богати, Ахъ! Я нещзасний, щз-эн маю діяти?;

6) в оформленні зворотних дієслів і в українській літературній мові, і в діалектах бере активну участь зворотна частка ся, що за походженням є зворотним займенником, проте тут маємо чимало відмінностей між діалектами. Щоправда, у південно-східних і поліських діалектах, а також у значній частині подільсько-волинських говорів південно-західних діалектів відмінностей між літературною мовою не виявляємо. У цих діалектах зворотна частка ся давно вже закріпилася в постпозиції й лексикалізувалася з дієсловом. Відчутні відмінності в оформленні зворотних дієслів спостерігаємо в південно-західних діалектах, зокрема й у частині подільських, де частка ся не злилася, не лексикалізувалася з дієсловом і може виступати стосовно нього і в препозиції, в постпозиції, перебуваючи іноді навіть на певній дистанції від дієслова. Таке явище відбивають і записи пісень: А зъвечера не видненько, Прийди, прийди, ме серденько; Вже минуло три неділі, Якь ми ся не виділи; Я дівкою піду де схочу, Я ся нічимъ не заклопочу; стойіть явіръ надъ водою, гілёмъ похилився; Якъ ся зъ тобой не оженю, не будуженився;

7) у досліджуваних текстах трапляються форми умовного способу, у яких до частки би в 1-ій особі одн. приєднується ще енклітичне закінчення, що є залишком допоміжного дієслова колишніх перфектних форм: Просивбимъ йі, щуоби мя кохала, Та-й щуобъ тамтого поперестала; Але не схоче, бо я не богати, Охъ! Я нещзасний, не могу йі взяти!; 
8) для творення описових форм наказового способу використовується й частка най (< нехай): Ой! Не вийшла дівчинонька, тилькі йейі мати: Кому треба мойій донькі, най іде до хати;

9) досить поширеним $є$ допустовий сполучник хоть, генетично пов'язаний, очевидно, з 2-ю особою одн. теперішнього часу дієслова хочеш [Булаховський 1949: 55]: Повій, повій, буйний вітре, по високій горі, Та розчеши кучерикі по мойій голові. Хоть я буду та по горі високій віяти, Такі треба кучерикі гребенемъ чесати;

10) усічення закінчень прикметників та присвійних займенників ж. р. в Д. в. і М. в. одн.: Просивемъ йі, щобь мене кохала, Щоби іншому серия не давала, А вона не хоче, бо я не богати, Ахъ! Я нещасний, що-жъ маю діяти?; Чи ти коню осідлани, чи ти коню сиви, Ой! А де-жъ ти одйіжджайешъ ть мій чорнобриви?.

Лексичні риси подільського говору значною мірою зумовлені не лише специфікою його внутрішнього розвитку, а й міждіалектними контактами в цьому мовному ареалі. Тому серед лексичних особливостей подільського говору відзначено чимало рис, що єднають цей говір з іншими сусідніми українськими говорами. Часто вживаними в текстах є діалектні словоформи бараболя, вуйко, n'єu, пляики, калабаня, файно, когут, дюрка та ін.: А не кури, вуйку, люльку въ мойейі хатині, Не викури очи чорні молодий дівчині; По тімъ боиі Дністра-води, гільтай сіно косить; По сімъ боиі Дністра-води, дівчина голосить.

Народнорозмовний і фольклорний синтаксис виявляє ,[...] всі ті відношення, які представлені в синтаксисі розвинутої літературної мови, але засоби цієї передачі часто економляться, уодноманітнюються" [Русанівський 1999: 9]. У фольклорному синтаксисі, як відомо, $є$ специфічні фігури, зокрема, що містять сполучник $m a$ не як приєднувальний, а як такий, що єднає два й більше сурядні присудки: Люди ходять та й гадають, Що за паня - не пізнають. Тра-ла-лай-ла-ла-ла. Виразною фольклорною ознакою є повтор: Взяли бабу під боки, під боки, під боки, Давай, бабо, горілки, горілки - бабо, Баба довго думала, довго думала, Піднялася та й дала, та й дала-горілки.

Етнографічними й фольклорними матеріалами, що зберігають цінні мовні свідчення, на нашу думку, також є українські народні пісні, записані на поч. XIX ст. відомим польським археологом, фольклористом та етнографом, дослідником давньої культури слов'ян Зоріаном Доленгою-Ходаковським. Як зазначають учені, його доробок — це набуток не тільки української, а й загальнослов'янської фольклористики, це перша спроба систематичного, усвідомленого записування пісенності українського народу в ії жанровій різноманітності, у великій кількості зразків і на широкій території - Галичині, Волині, Поділлі, Поліссі й Наддніпрянщині. Більшість пісень, записаних ним, збереглася до нашого часу в рукописах-автографах і копіях з його 
записів. 3 автографів дійшли до нас три збірники: перший - без заголовка, писаний латинкою; другий — під заголовком Лелева російським правописом поч. XIX ст. (обидва вони зберігаються у відділі рукописів Інституту літератури ім. Т.Г.Шевченка НАН України, ф. 99, од. зб. 199 і 188 відповідно); третій автограф, названий збирачем Śpiewy stowiańskie pod strzecha wiejska zbierane, знаходиться в Тернопільському краєзнавчому музеї, куди він потрапив від спадкоємців архіву В. Гнатюка [Дей 1973: 91]. Українські, білоруські та польські пісні подано латинкою, російські — гражданським правописом. Українських пісень у рукописах фольклориста дослідники його творчості нараховують понад дві тисячі й, на жаль, вони й досі належно не поціновані, а насамперед мовознавцями-діалектологами. Цінність рукописів полягає не лише в багатстві матеріалів, записаних безпосередньо з уст народу на широкій території, а й у тому, що 3. Доленга-Ходаковський у своїх записах нерідко прагнув також зберегти діалектні особливості мови, передати живе звучання, вимову певних слів і звуків.

Зафіксовані дослідником пісні зберігають значну кількість слів і висловів, що сьогодні або не вживаються в українській літературній мові, або ж побутують лише на певній території, про що свідчить їхня фіксація в словниках української мови з ремарками діал. та засm., напр.: доїдати - діал. ‘набридати, досаджати, докучати' [Словник української мови 1971, 2: 349]; зуміти - 'думати, міркувати' (лексема зу́міти не фіксується в Словнику украӥнської мови, однак вона є в Словарі украӥнської мови Б. Грінченка зі значенням 'зійти з розуму' та з покликанням на Подільську губернію) [Словарь української мови 1996, 2: 188]; одвітати — 'відповідати' (відвіт - заст. ‘відповідь') [Словник української мови 1970, 1: 565]; заушниці - діал. 'сережки' [Словник української мови 1972, 3: 63]; ловчик - 'мисливець' [Словарь української мови 1996, 2: 373] та ін. Дослідник українських народних пісень О. Дей наводить ще й такі архаїчні лексеми і їхнє значення, які трапляються в рукописах 3. Доленги-Ходаковського: ісходеньки - 'ступеньки східців'; кудра — 'крона дерева'; скупити — 'зсадити, зняти': „як би нам скупити сокола з явора; повні повниці - 'повні келехи'; коло кур приїздти — 'рано'; необмівции — „тепер люди - необмівци, где ся зойдут, все об дівцчи”; слідоньки слідувати, леть звисочка та ін. [Дей 1975: 38].

У цих піснях фіксуємо форми: а) старого Зн. в. замість Р. в.: На Івася-бояре (тобто на Івасевих бояр); б) колишнього Ор. в. іменників о-основ: Шлет мене по водииу з великими да відерцин; в) Д. в. самостійного: Бо за старого ідучи, із шанти вінки в 'ючи: за молодого ідучи, — з рутки вінки в 'ючи; г) колишню форму Н. в. мн. у-основ: Щось нам двір покопало [...] - чи з ліса медведове,чи зо села сватенькове?; д) форми двоїни: Ой чи диво, чи не диво: Звойовали дівки дві місті, Молодици дві селі [...], Не журися, дівчино, тій великій шкоді, Маю пару лебедів, пошлю їх проти воді. 
Цінною бібліографічною рідкістю є Словничок провінціалізмів подільських, укладений в Кам'яниі-Подільському в роиі 1863 А. Кремера, що виданий у Кракові [Kremer 1870]. У цій праці після передмови подається список “подільських провінціалізмів", а потім - список "русизмів”, поширених на Поділлі. Автор пояснює, що до першого списку ввійшли українські слова й вислови, що $є$ в мові польської шляхти на Поділлі. Ця шляхта, хоч і говорить польською мовою, не забула й мови української (języka ruskiego) й тому вживає українські слова й звороти, засвоєні через повсякденне спілкування із селянами, особливо слова-назви сільськогосподарських знарядь, їхніх частин, будівель, ділянок поля, лісу й т. ін. У цей список внесено 952 таких слова та вислови. У другому списку подано 125 слів-русизмів, уживаних у мові подільської шляхти, засвоєних "w najnowszych czasach" з російської мови (z języka rosyjskiego) [Kremer 1870: 2-3].

Як зазначає автор, він 24 роки перебував у столиці Поділля - Кам'янці-Подільському, прислухався до мови його мешканців, збирав матеріал разом зі своїм помічником Альбіном Гославським та зрештою видав словничок мови городян. Спонукала його до цього та обставина, що на мовлення подолян, зокрема кам'янчан, значний вплив мала російська мова, особливо „після впровадження, під час панування Миколая, російських правил і наказу вживання в школах російської мови як мови викладання" [Kremer 1870: 3]. А. Кремер розмістив слова за абеткою, використавши транслітерацію, а тлумачення слів подав польською мовою, посилаючись на словник Самуїла Лінде [Linde 18541859]. Зрозуміло, що не всі слова укладач міг віднайти в словнику польської мови, тому досить часто подавав тлумачення слів і фразеологізмів 3 тими значеннями, з якими вони функціювали в мові мешканців міста, указуючи, що „у Лінде немає такого значення”, напр.: арбуз (Arbuz) - кладеться до брички кавалера, якого панна не хоче за чоловіка; гарбуза дати - 'відмовити в заміжжі' (у словнику Лінде немає такого значення) [Kremer 1870: 4].

Чимало зафіксовано в словнику номінацій, що й досі побутують у мовленні кам'янчан, а до сучасних тлумачних словників увійшли з ремарками діал., заст., розм. або ж узагалі не зафіксовані, напр.: дуля, розм. - 'сорт груші' [Словник української мови 1971, 2: 434]; гладущик, діал. - 'широкий глек для молока' [Словник української мови 1971, 2: 79]; кабак, діал. 'гарбуз' [Словник української мови 1973, 4: 63]; пантрувати, розм. - 'дивитися пильно, уважно' [Словник української мови 1975, 6: 51]; napacmac, заст. - 'заупокійна управа' [Словник української мови 1975, 6: 66]; пузо, розм. - 'великий живіт' [Словник української мови 1977, 8: 86]; рискаль, діал. - 'заступ' [Словник української мови 1977, 8: 539]; фаєрка — 'конфорка' [не зафіксовано].

Отже, тексти пісень Поділля, незважаючи на нейтралізацію виразних діалектних особливостей унаслідок “переживання" народної пісні митцем, від- 
бивають певною мірою місцеві вимовні риси. Як зазначає В. Русанівський, „3 одного боку, народна пісня відмовляється від вузьколокальних варіантів форм, особливо тих, що виникли внаслідок накладання однієї моделі на іншу, а 3 другого - в ній простежується культивування, підтримання в активному стані традиційних варіантних форм, що втрачені в побутовому мовленні” [Русанівський 1999: 8]. Наведені зразки лінгвальних особливостей записів 3. Доленги-Ходаковського та А. Коціпінського переконують у тому, що, поперше, записи фольклористів невтратили своєїцінності йдо сьогодні; по-друге, $\epsilon$ нагальна потреба їхнього всебічного опрацювання 3 метою вивчення народного мовлення тієї території й того часу. Словничок подільських провіниіалізмів може бути цікавим з огляду на вивчення впливу однієї мови на іншу (у цьому разі - української й російської на польську), а також тим, що в ньомує чимало західноукраїнських слів, значення яких розкривають польські переклади або пояснення.

\section{Список використаної літератури}

Аркушин Г. Л., Мова фольклору і говіркове мовлення, [в:] Народна творчість украӥниів y просторі і часі: матер. міжнар. наук. конф. в рамках VI Міжнародного фестивалю українського фольклору „Берегиня”, Луцьк 2010, с. 206-214.

Бевзенко С. П., Украӥнська діалектологія, Київ: Вища школа, 1980.

Болтарович 3. Є., Україна в дослідженнях польських етнографів XIX cm., Київ: Наукова думка, 1976.

Булаховський Л. А., 3 історичних коментарів до украӥнської мови. Сполучники і сполучні групи (речення). Синтаксичні особливості при них, [в:] „Наукові записки КДУ”, 1946, т. 5, вип. 2, с. 31-71.

Гороф'янюк I. В., Зі спостережень над фольклорними текстами як джерелом вивчення діалектного мовлення подолян, [в:] „Волинь філологічна: текст і контекст”, 2013, вип. 15 , с. $66-74$.

Грицевич Ю. В., Фольклорні тексти як діалектографічний матеріал у сучасному українському мовознавстві, [в:] „Львівський філологічний часопис”, 2018, № 3, с. 72-76.

Гриценко П. Ю., Про один тип джерел сучасних діалектологічних студій, [в:] Діалекти в синхронії та діахронії: загальнослов'янський контекст, тези доп. міжнар. конф., Київ: КММ, 2014, с. 145-154.

Громик Ю. В., Фольклорні матеріали з Берестейщини як діалектографічний матеріал, [в:] „Справа: беларуска-ўкраінскі альманах Таварыства украінскай літаратуры пры Саюзе беларускіх пісьменнікаў”, 2015, № 1, с. 162-169.

Данилюк Н. О., Діалектні явища у мові волинських народних niceнь, [в:] Ukraińskie i polskie gwary pogranicza, Lublin; Łuck: Polskie Towarzystwo Ludoznawcze, 2001, c. 125-126.

Дей О. І., Автограф Слов'янських пісень 3. Доленги-Ходаковського - знайдено, [в:] „Народна творчість та етнографія”, 1973, № 1, с. 91-94. 
Єрмоленко С. Я., Фольклор і літературна мова, Київ: Наукова думка, 1987.

Кирчів Р. Ф., Український фольклор у польській літературі (період романтизму), Київ: Наукова думка, 1971.

Коваленко Б. О., Діалектна основа жартівливих пісень з Поділля, [в:] „Вісник Прикарпатського національного університету. Філологія (Мовознавство)”, 2009, вип. XXIXXII, c. 42-45.

Матвіяс I. Г., Відображення говорів у мові украйнських історичних пісень і народних дум, [в:] „Українська мова”, 2005, № 1, с. 52-59.

Новицький О. М., Фольклористична та етнографічна діяльність А. І. Димінського, [в:] „Народна творчість та етнографія”, 1980, № 6 (166), с. 38-42.

Паравійчук А. Г., Видатний історик Поділля Ю. Й. Сіиінський, [в:] „Український історичний журнал”, 1968, № 9, с. 87-92.

Русанівський В. М., I з Уманщиини, і з усієї України (народнорозмовне джерело мови T. Шевченка), [в:] „Мовознавство”, 1999, № 2-3, с. 3-10.

Сиваченко М. Є., Анатолій Свиднищький $і$ зародження сочіального роману вукрайнській літературі, Київ: Вид-во АН УРСР, 1962.

Сиваченко М. Є., Новознайдені оповідання А. П. Свидницького і їх фольклорні джерела, [в:] Літературознавчі та фольклористичні розвідки, Київ: Наукова думка, 1974, c. $147-182$.

Фроляк Л. Д., До питання про народні пісні з Підляшшя як джерело діалектологічних студій, [в:] „Teka Komisji Polsko-Ukraińskich Związków Kulturowych”, 2016, vol. XI, s. $35-42$.

Юзвенко В. А., Украӥнська народна поетична творчість у польській фольклористиці ХІХ cm., Київ: Вид-во АН УРСР, 1961.

\section{Spysok vykorystanoi literatury [References]}

Arkushyn H. L., Movafolkloru i hovirkove movlennia [Language of Folklore and Dialect Speech], [v:] Narodna tvorchist ukraintsiv u prostori i chasi, mater. mizhnar. nauk. konf. v ramkakh VI Mizhnarodnoho festyvaliu ukrainskoho folkloru „Berehynia”, Lutsk 2010, s. 206-214.

Bevzenko S. P., Ukrainska dialektolohiia [Ukrainian Dialectology], Kyiv: Vyshcha shkola, 1980. Boltarovych Z. Ye., Ukraina v doslidzhenniakh polskykh etnohrafiv XIX st. [Ukraine in Research Works of Polish Ethnographers of the XIX Century], Kyiv: Naukova dumka, 1976.

Bulakhovskyi L. A., Z istorychnykh komentariv do ukrainskoi movy. Spoluchnyky i spoluchni hrupy (rechennia). Syntaksychni osoblyvosti pry nykh [From Historical Comments about Ukrainian Language. Conjunctions and Conjunctive Groups (Sentences). Syntactic Features of Them], [v:] „Naukovi zapysky KDU”, 1946, t. 5, vyp. 2, s. 31-71.

Horofianiuk I. V., Zi sposterezhen nad folklornymy tekstamy yak dzherelom vyvchennia dialektnoho movlennia podolian [From Observations on Folklore Texts as a Source for the Studying the dialEctal Speech of Podillians], [v:] „Volyn filolohichna: tekst i kontekst”, 2013, vyp. 15, s. 66-74. 
Hrytsevych Yu. V., Folklorni teksty yak dialektohrafichnyi material u suchasnomu ukrainskomu movoznavstvi [Folklore Texts as Dialectographic Material in Contemporary Ukrainian Linguistics], [v:] „Lvivskyi filolohichnyi chasopys”, 2018, № 3, s. 72-76.

Hrytsenko P. Yu., Pro odyn typ dzherel suchasnykh dialektolohichnykh studii [About One Type of Sources of Modern Dialectological Studies], [v:] Dialekty v synkhronii ta diakhronii: zahalnoslovianskyi kontekst, tezy dop. mizhnar. konf., Kyiv: KMM, 2014, s. $145-154$.

Hromyk Yu. V., Folklorni materialy z Beresteishchyny yak dialektohrafichnyi material [Folk Materials from Beresteyschyna as Dialectographic Material], [v:] „Sprava: belaruskawkrainski al"manah Tavarystva ukrainskaj litaratury pry Sajuze belaruskih pis"mennikaw", 2015, № 1, s. 162-169.

Danyliuk N. O., Dialektni yavyshcha u movi volynskykh narodnykh pisen [Dialect Phenomena in the Language of Volyn Folk Songs], [v:] Ukraińskie i polskie gwary pogranicza, Lublin; Łuck: Polskie Towarzystwo Ludoznawcze, 2001, s. 125-126.

Dei O. I., Avtohraf Slovianskykh pisen Z. Dolenhy-Khodakovskoho — znaideno [Autograph of Slavonic Songs by Z. Dolenha-Khodakovskyi - found], [v:] „Narodna tvorchist ta etnohrafiia”, Kyiv 1973, № 1, s. 91-94.

Yermolenko S. Ya.,Folklor i literaturna mova [Folklore and Literary Language], Kyiv: Naukova dumka, 1987.

Kyrchiv R. F., Ukrainskyi folklor u polskii literaturi (period romantyzmu) [Ukrainian Folklore in Polish Literature (the Period of Romanticism], Kyiv: Naukova dumka, 1971.

Kovalenko B. O., Dialektna osnova zhartivlyvykh pisen z Podillia [The Dialectal Basis of Humorous Songs from Podillia], [v:] „Visnyk Prykarpatskoho natsionalnoho universytetu. Filolohiia (Movoznavstvo)", 2009, vyp. XXI-XXII, s. 42-45.

Matviias I. H., Vidobrazhennia hovoriv u movi ukrainskykh istorychnykh pisen i narodnykh dum [Reflection of Dialects in the Language of Ukrainian Historical Songs and Folk Dumas], [v:] „Ukrainska mova”, 2005, № 1, s. 52-59.

Novytskyi O. M., Folklorystychna ta etnohrafichna diialnist A. I. Dyminskoho [Folklore and Ethnographic Works of A. I. Dyminskyi], [v:] „Narodna tvorchist ta etnohrafiia”, 1980, № 6 (166), s. 38-42.

Paraviichuk A. H., Vydatnyi istoryk Podillia Yu. Y. Sitsinskyi [Outstanding Historian of Podillia Region Yu. Y. Sitsinskyi], [v:] „Ukrainskyi istorychnyi zhurnal”, 1968, № 9, s. 87-92.

Rusanivskyi V. M., I z Umanshchyny, i z usiiei Ukrainy (narodnorozmovne dzherelo movy T.Shevchenka) [From Uman Region and from All Over Ukraine (Folk Source of T. Shevchenko's Language)], [v:] „Movoznavstvo”, 1999, № 2-3, s. 3-10.

Syvachenko M. Ye., Anatolii Svydnytskyi i zarodzhennia sotsialnoho romanu v ukrainskii literaturi [Anatolyi Svydnytskyi and Arising of a Social Novel in Ukrainian Literature], Kyiv: Vyd-vo AN URSR, 1962.

Syvachenko M. Ye., Novoznaideni opovidannia A. P. Svydnytskoho i yikh folklorni dzherela [Newly-Discovered Stories by A.P.Svydnytskyi and Their Folk Sources], [v:] Literaturoznavchi ta folklorystychni rozvidky, Kyiv: Naukova dumka, 1974, s. 147-182.

Froliak L. D., Do pytannia pro narodni pisni z Pidliashshia yak dzherelo dialektolohichnykh studii [To the Question of Folk Songs from Podlasie as a Source of Dialectological Studies], 
[v:] „Teka Komisji Polsko-Ukraińskich Związków Kulturowych”, 2016, vol. XI, s. 35-42. Yuzvenko V.A., Ukrainska narodna poetychnatvorchist u polskiifolklorystytsiXIX st. [Ukrainian

Folk Poetry in the Polish Folkloristics of the XIX Century], Kyiv: Vyd-vo AN URSR, 1961.

\section{Список використаних джерел}

Коціпіньскій А., Пісьні, думкі і шумкі руського народа на Подолі, Украіні і въ Малороссійі,

Кіевъ: Видавець А. Г. Коціпіньскій, 1862.

Словарь украӥнської мови, в 4 томах, упоряд. Б. Д. Грінченко, Київ: Наукова думка, 1996.

Словник украӥнської мови, в 11 томах, ред. І. К. Білодід, Київ: Наукова думка, 1970-1980.

Kremer A., Słowniczek prowincializmów podolskich, ułozony w Kamieńcu Podolskim w roku

1863, Kraków: Drukarnia uniwers. Jagiellońskiego, 1870.

Linde M. S. B., Słownik języka polskiego, Lwów: Zakład Narodowy im. Ossolińskich, 18541859.

\section{Spysok vykorystanykh dzherel [References]}

Kotsipinskii A., Pisni, dumki i shumki ruskoho naroda na Podoli, Ukraini $i$ vъ Malorossiii [Songs, Dumkas and Shumkase of Rus' People in Podillia, Ukraine and in Malosossiia], Kievъ: Vydavets A. H. Kotsipinskii, 1862.

Slovar ukrainskoi movy [Dictionary of Ukrainian Language], v 4 tomakh, uporiad.

B. D. Hrinchenko, Kyiv: Naukova dumka, 1996.

Slovnyk ukrainskoi movy [Dictionary of Ukrainian Language], v 11 tomakh, red. I. K. Bilodid, Kyiv: Naukova dumka, 1970-1980.

Kremer A., Słowniczek prowincializmów podolskich, ułozony w Kamieńcu Podolskim w roku 1863 [Dictionary of Podillian Provincialism, Compiled in Kamianets-Podilskyi in 1863], Kraków: Drukarnia uniwers. Jagiellońskiego, 1870.

Linde M. S. B., Stownik języka polskiego [Dictionary of Polish language], Lwów: Zakład Narodowy im. Ossolińskich, 1854-1859. 